\title{
Silicon Nitride Capacitive Chemical Sensor for Phosphate Ion Detection Based on Copper Phthalocyanine - Acrylate-polymer
}

Lassaad Barhoumi, ${ }^{[\mathrm{a}, \mathrm{b}]}$ Abdoullatif Baraket, ${ }^{[\mathrm{dd}]}$ Naglaa Mohammed Nooredeen, ${ }^{[\mathrm{c}]}$ Mounir Ben Ali, ${ }^{[\mathrm{a} \text {, }}$

b], Mohammed Nooredeen Abbas, ${ }^{[\mathrm{e}]}$ Joan Bausells, ${ }^{[\mathrm{f}]}$ and Abdelhamid Errachid ${ }^{[\mathrm{d}]}$

[a] L. Barhoumi, M. B. Ali, University of Sousse, Higher Institute of Applied Sciences and Technology of Sousse, GREENS-ISSAT, Cit Ettafala, 4003 Ibn Khaldoun Sousse, Tunisia.

[b] L. Barhoumi, M. B. Ali, NANOMESENE Lab, LR16CRMN01, Centre for Research on Microelectronics and Nanotechnology of Sousse, Technopole of Sousse B. P. 334, Sahloul, 4034, Sousse, Tunisia.

[c] N. M. Nooredeen, Polymer and Pigments Department, National Research Centre, Cairo, Egypt.

[d] A. Baraket, A. Errachid, Université de Lyon, Institut des Sciences Analytiques, UMR 5280, CNRS, Université Lyon

1, ENS Lyon - 5, rue de la Doua, F-69100 Villeurbanne, France. E-mail: abdoullatif.baraket@isa-lyon.fr.

[e] M. N. Abbas, Analytical Laboratory, National Research Centre, Cairo, Egypt.

[f] J. Bausells, Centro Nacional de Microelectrnica (CSIC), Campus UAB, 08193 Bellaterra, Spain.

\begin{abstract}
In this work, we report the development of a highly sensitive capacitance chemical sensor based on a copper C,C,C,C-tetra-carboxylic phthalocyanine-acrylate polymer adduct $(\mathrm{Cu}$ (II)TCPc-PAA) for phosphate ions detection. A capacitance silicon nitride substrate based $\mathrm{AlCu} / \mathrm{Si}-\mathrm{p} / \mathrm{SiO}_{2} / \mathrm{Si}_{3} \mathrm{~N}_{4}$ structure was used as transducer. These materials have provided good stability of electro- chemical measurements. The functionalized silicon-based transducers with a $\mathrm{Cu}(\mathrm{II}) \mathrm{Pc}-\mathrm{PAA}$ membrane were characterized by using Mott-Schottky technique measurements at different frequency ranges and for different phosphate concentrations. The morphological surface of the $\mathrm{Cu}$ (II) Pc-PAA modified silicon-nitride based transducer was characterized by contact angle measurements and atomic force microscopy. The $\mathrm{pH}$ effect was also investigated by the Mott-Schottky technique for different Tris$\mathrm{HCl}$ buffer solutions. The sensitivity of silicon nitride was e studied at different $\mathrm{pH}$ of Tris-HCl buffer solutions. This $\mathrm{pH}$ test has provided a sensitivity value of $51 \mathrm{mV} /$ decade. The developed chemical sensor showed a good performance for phosphate ions detection within the range of $10^{-10}$ to $10^{-5} \mathrm{M}$ with a Nernstian sensitivity of $27.7 \mathrm{mV} /$ decade. The limit of detection of phosphate ions was determined at $1 \mathrm{nM}$. This chemical sensor was highly specific for phosphate ions when compared to other interfering ions as chloride, sulfate, carbonate and perchlorate. The present capacitive chemical sensor is thus very promising for sensitive and rapid detection of phosphate in environmental applications.
\end{abstract}

Keywords: Capacitive chemical sensor $\cdot$ phthalocyanine-acrylate $\cdot$ phosphate ions $\cdot$ Mott-Schottky 


\section{Introduction}

The global demand for minerals and metals is always permanent, and this in turn is causing growing concerns about long-term environmental security. Phosphate is widely used for agriculture in the world because it is an essential nutrient. This is what makes the global consumption of phosphate raise from 43.7 million tons in 2015 to 48.2 million tons expected to be consumed in 2019 [1]. The economic geography of the world phosphate industry has been changed over the past two decades regarding the phosphate consumption. The USA was the leading producer of phosphate in 1989 (50 million tonnes), covering the $30.2 \%$ of world production. The Soviet Union was next with 37.5 million tonnes (22.8\%), followed by China (12.1\%) and Morocco (11\%). About 35 other countries shared the remaining production, and Kazakhstan, Egypt, Jordan, Togo, Tunisia, Peru, Russia and Brazil resulted the most prominent [2]. Phosphate mining is considered the main cause of many diseases, such as allergies, respiration, dental fluorosis, stress, cardiovascular and cancer. The latter represent the primary environmental cause of mortality, especially as regards children and phosphate miners [3]. These diseases are directly related to the installation of the industrial sector of phosphate mines in addition to deforestation and the ecosystem degradation.

Therefore, chemical sensors are of growing importance in environmental analysis, especially in monitoring liquid quality. These sensors are common for the selective detection of ions, especially for applications of monitoring small organic pollutants in water. These devices can continuously and selectively detect the levels of phosphate in aqueous solution [4], in order to monitor the levels of toxic substances, such as phosphate. These chemical sensors have found numerous applications in different fields like environmental monitoring, where eutrophication is a problem caused in part by leaching inorganic phosphate into farmland an streams [5]. Phosphate is also used in biomedical research, clinical chemistry and pharmacology $[6,7]$.

Recently, the class of metallo-phthalocyanine (MPc) materials, which have a metal atom located in the central cavity [8], have been of great interest due to their excellent electronic properties and potential applications for the detecting targeted ions [9]. The response of sensors based on MPcs doping as sensitive membrane electrodes is believed to be based on the coordination of the analyte ion as an axial ligand with the metal center of the carrier molecule. Changing the central metal of these complexes strongly influences their selectivity $[8,10]$. The MPcs were widely used in a lot of fields, such as gas sensors [11] and biosensors [12, 13], and receive a considerable attention because of the increasing importance as chemical sensors $[14,15]$ especially for the detection of toxic anions. Moreover, the MPcs provide high chemical and thermal stability as well as a tendency to form highly ordered layers that positively influence the device efficiency [16]. This new nanomaterial was used to develop the present chemical sensor for phosphate detection. This material is compatible with integrated circuit technology (IC) and has been used in chemical sensors $[17,18]$.

Moreover, the covalent binding of the ionophore C,C,C,C-tetra-carboxylic phthalocyanine-acrylate polymer adduct ( $\mathrm{Cu}(\mathrm{II}) \mathrm{TCPc}-\mathrm{PAA})$ gives long-term stability by preventing the ionophore from leaching into the sample solution, crystallizing or evaporating. Furthermore, this ionophore improves the sensor selectivity and detection limit [19]. 
In this work, we study a new synthesized copper, C,C,C,C-tetra-carboxylic acid- polyacrylamide $(\mathrm{Cu}(\mathrm{II}) \mathrm{Pc}-\mathrm{PAA})$ as a selective ionophore for phosphate [20]. In this context, a novel electrochemical capacitive sensors based on $\mathrm{AlCu} / \mathrm{Si}-\mathrm{p} / \mathrm{SiO}_{2} / \mathrm{Si}_{3} \mathrm{~N}_{4}$ substrates and functionalized with copper phthalocyanine derivative have been developed. The modified transducer surfaces have been characterized using contact angle measurements and Atomic Force Microscopy (AFM). The capacitive sensor response towards phosphate ions has been tested in high $(10 \mathrm{kHz})$ and low (100 $\mathrm{Hz}$ ) frequencies using Mott-Schottky electrochemical technique.

\section{Experimental Details}

\subsection{Material}

Tetrahydrofuran (THF) was obtained from Fluka Analytical, France. Dimethyl sulfoxide (DMSO), Tris(hydroxymethyl) aminomethane, Hydrogen peroxide $\mathrm{H}_{2} \mathrm{O}_{2}(35 \%)$, sulfuric acid $\left(\mathrm{H}_{2} \mathrm{SO}_{4}\right)$ and phosphate $\mathrm{K}_{2} \mathrm{HPO}_{4}$ were purchased from Sigma Aldrich France. Phosphate ions were obtained from dibasic potassium phosphate $\mathrm{K}_{2} \mathrm{HPO}_{4}$. Different solutions of the ions were prepared in aqueous medium at various concentrations. The key ionophore, which was the copper Phthalocyanine, C,C,C,C-tetra-carboxylic acid-polyacrylamide $\left(\mathrm{C}_{32} \mathrm{H}_{16} \mathrm{~N}_{8}\right)$, was synthesized in the National Research Centre in Cairo(Egypt), and it was composed of four isoindoles (a benzene fused to a pyrrole ring) connected to nitrogen atoms and had a central copper atom. This new nanomaterial was used to develop the present chemical sensor for phosphate detection. All solutions were prepared in ultrapure water (Millipore $18 \mathrm{MW} . \mathrm{cm}$ ) and phosphate sensors ware tested in a Tris- $\mathrm{HCl}$ buffer solution $0.1 \mathrm{M}$.

\subsection{Instrumentation}

\subsubsection{Wettability}

The hydrophilicity of the immobilized Cu-Pc(II)-PAA membrane was investigated by contact angle measurements using 'Digidrop' from GBX (France). $5 \mathrm{~mL}$ of deionized water was dropped on the sensing film surface through the application nozzle at $258 \mathrm{C}$. The digital camera associated with the instrument acquired the image and analyzed the water droplet behavior. The contact angle was obtained for five different areas of a given wafer with five separated droplets and the statistical average of the five measurements was calculated. The volume and size of the drops were kept constant.

\subsubsection{Atomic Force Microscopy (AFM)}

The AFM characterization was performed using a Nano observer SCIEN Tec (France). The AFM Nano-Observer had a maximum scan area of $110 \mu \mathrm{m}^{2}$ and a minimum of $0.2 \mu \mathrm{m}^{2}$. The measurements were made using a silicon cantilever tip (Scien TecApp Nano). The cantilever contained a silicon tip bearing an integrated standard profile tip with a nominal spring constant at $25-75 \mathrm{~N} / \mathrm{m}$ in the frequency range of $200400 \mathrm{KHz}$ with a length of $125 \mu \mathrm{m}$, a width of $35 \mu \mathrm{m}$, and a thickness of 4.5 $\mu \mathrm{m}$. The tip radius was lower than $10 \mathrm{~nm}$ and the tip height was $14-16 \mu \mathrm{m}$. The imagining was performed at $5 \mathrm{~V}$ of amplitude, a set point of $8 \mathrm{~V}$, a tip DC at $477 \mathrm{nV}$, and a frequency of $337 \mathrm{kHz}$. These measurements were carried out in a 'tapping-mode' (TM-AFM) which was used with a speed of $0.5 \mathrm{line} / \mathrm{s}$ and a resolution of 1024 lines. Samples were analyzed in a $5 \mu \mathrm{m}$ x $5 \mu \mathrm{m}$ area. 


\subsubsection{Electrochemical Analysis}

All electrochemical capacitance measurements were carried out at room temperature in a Faraday box, using a VMP3 potentiostat (16 channels BioLogic France) which was monitored by EC-Lab software. Mott-Schottky capacitance measurements were performed in a three-electrode electrochemical cell (Platinum counter electrode, $\mathrm{Ag} / \mathrm{AgCl}$ reference electrode and a functionalized $\mathrm{AlCu} / \mathrm{Si}-\mathrm{p} / \mathrm{SiO}_{2} / \mathrm{Si}_{3} \mathrm{~N}_{4}$ structure as a working electrode). The cell was connected to the potentiostat. The capacitance-voltage measurements were carried out within the potential range of -0.5 to $2 \mathrm{~V}$ at high frequency $(10 \mathrm{kHz})$ and at low frequency $(100 \mathrm{~Hz})$ with a signal amplitude of $10 \mathrm{mV}$. All measurements were made with a $5 \mathrm{~mL}$ freshly prepared Tris-HCL solution $(10 \mathrm{mM}$ and $\mathrm{pH}=7.2)$.

\subsection{Synthesis of Sensitive Molecule Copper Phthalocyanine}

The novel phthalocyanine derivative $\mathrm{Cu}-\mathrm{Pc}(\mathrm{II})-\mathrm{PAA}$ (Figure 1) was synthesized in the National Research Centre of Cairo. The ionophore Copper phthalocyanine-C,C,C,C-tetra-carboxylic acid (I) and the adduct of copper phthalocyanine-C,C,C,C-tetra-carboxylic acid-PAA (II) were synthesized according to (Figure 1) and characterized by elemental analysis and UV-Vis and IR spectroscopy [21]. Briefly, the condensation of trimellitic anhydride in the presence of urea, ammonium molybdate and copper acetate was used to form the tetra-formamide phthalocyanine copper. Ionophore (I) was obtained by hydrolyzing the product in an alkaline medium. The ionophore-polymer was synthesized by condensing the carboxylic group of ionophores (I) with the $\mathrm{NH}_{2}$ groups of PAA by refluxing it in dimethylformamide (DMF) at $150^{\circ} \mathrm{C}$ in the presence of polyphosphoric acid, adopting a previously reported procedure [22].

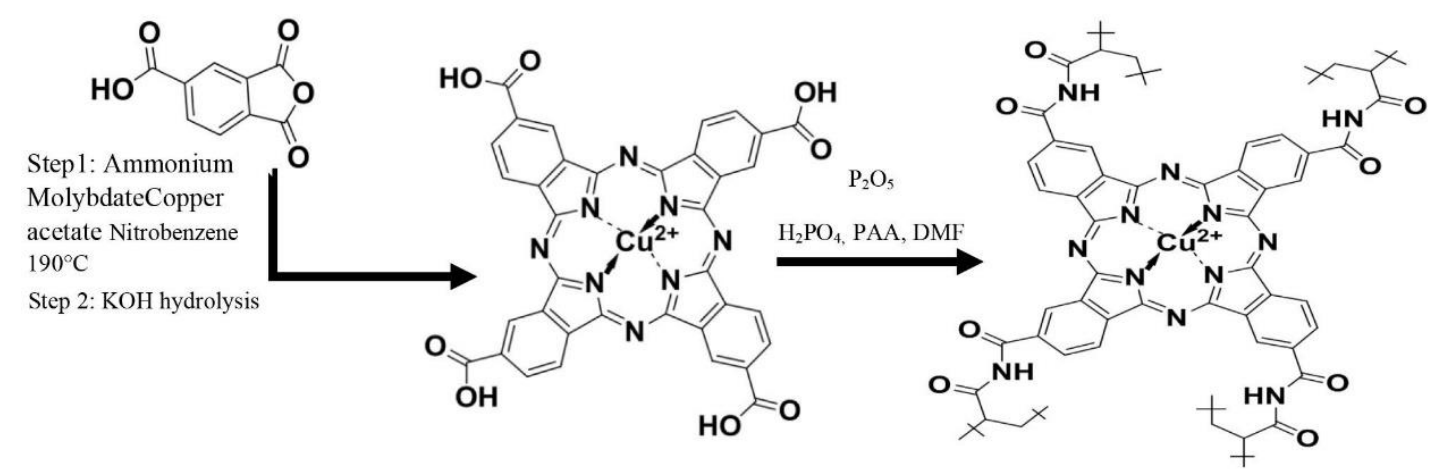

Fig. 1. Synthesis of Copper Phthalocyanine, 2,9,16,23-tetracarboxylic acid-Polyacrylamide (TCCu(II)Pc-PAA ionophore (II).

\subsection{Capacitance Electrode Preparation}

The planar capacitance sensor based on silicon nitride was fabricated from a p-type silicon substrate, with a $<100>$ orientation and $4-40 \Omega \cdot \mathrm{cm}^{1}$ resistivity. A thin layer of $78 \mathrm{~nm}$ thickness of silicon dioxide $\left(\mathrm{SiO}_{2}\right)$ was grown thermally onto the silicon surface followed by a deposition of $100 \mathrm{~nm}$ of silicon nitride $\left(\mathrm{Si}_{3} \mathrm{~N}_{4}\right)$ prepared by Low-Pressure Chemical-Vapor Deposition (LPCVD). The electrical contact on the silicon backside was obtained by over doping it with boron ions and a deposition of 1 
$\mu \mathrm{m}$ of an $\mathrm{Al} /(1 \% \mathrm{Cu})$ alloy. Finally, the wafers consisting of $\mathrm{AlCu} / \mathrm{Si}-\mathrm{p} / \mathrm{SiO}_{2} / \mathrm{Si}_{3} \mathrm{~N}_{4}$ were diced into single chips of $1 \mathrm{~cm}^{2}$, which presented the working electrode (Figure 2).

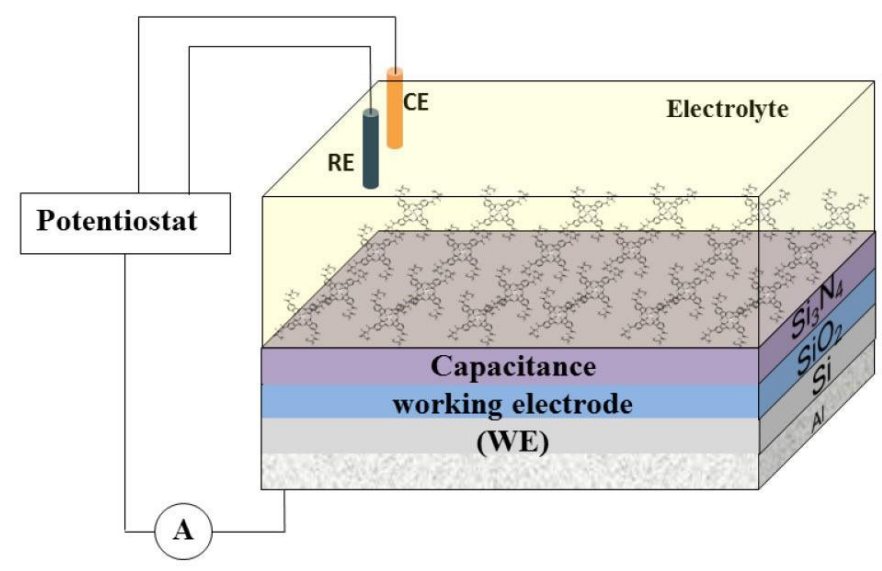

Fig. 2. Scheme of electrochemical capacitance ion sensor based on $\mathrm{AlCu} / \mathrm{Si}-\mathrm{p} / \mathrm{SiO}_{2} / \mathrm{Si}_{3} \mathrm{~N}_{4}$ structure and functionalized with sensitive layer of $\mathrm{Cu}(\mathrm{II})$ Pc-PAA for phosphate ion detection.

The $\mathrm{AlCu} / \mathrm{Si}-\mathrm{p} / \mathrm{SiO}_{2} / \mathrm{Si}_{3} \mathrm{~N}_{4}$ substrate was cleaned twice with acetone for 15 min by sonication, rinsed with distilled water, and finally dried under nitrogen flow. In the second step, the silicon nitride surface was activated with a piranha solution (1/3 hydrogen peroxide, $\mathrm{H}_{2} \mathrm{O}_{2}$, and $2 / 3$ sulfuric acid, $\mathrm{H}_{2} \mathrm{SO}_{4}$ ) for $30 \mathrm{~min}$. The piranha solution was in contact only with the $\mathrm{Si}_{3} \mathrm{~N}_{4}$ surface in order to protect the backside of the working electrode preventing the aluminum etching. The piranha activation generates silanol $(\mathrm{Si}-\mathrm{OH})$ and silylamine $(\mathrm{Si}-\mathrm{NH})$ groups [23] onto the silicon nitride surface, which led to a good adhesion of the derivative membrane of copper phthalocyanine $\mathrm{Cu}$ (II) Pc-PAA. Finally the working electrode was abundantly washed with distillated water and dried under nitrogen flow. The $\mathrm{Cu}$ (II)Pc-PAA solution in DMSO $(5 \mathrm{mg} / \mathrm{mL})$ was diluted with THF to obtain $1 \mathrm{mg} / \mathrm{mL}$ of ionophore solution. Then, $30 \mu \mathrm{L}$ of the dilute solution was dropcasted onto the activated surface of $\mathrm{Si}_{3} \mathrm{~N}_{4}$ and then dried at room temperature for $24 \mathrm{hr}$.

\section{Surface and Morphological Characterization}

\subsection{Contact Angle Measurements}

To control each modification step, the working electrode surface was characterized before and after each functionalization procedure by Contact Angle Measurements (CAM). The contact angles were determined from the droplet image using the tangent method. The liquid was deposited on solid surfaces with a micrometric syringe and controlled by means of a camera. Figure 3 presents the results of the water CAM of a bare $\mathrm{Si}_{3} \mathrm{~N}_{4}$ surface, after piranha treatment and after functionalization with $\mathrm{Cu}(\mathrm{II}) \mathrm{Pc}-\mathrm{PAA}$. 
The hydrophilicity of the surface substrate increased significantly after the piranha treatment as the $\mathrm{CAM}$ has decreased from 638 for a bare $\mathrm{Si}_{3} \mathrm{~N}_{4}$ to 248 after piranha treatment (Figure 3B). This was due to the formation of the hydroxyl groups onto the silicon nitride surface. These would help to attach the polymeric membrane afterwards. The phtalocyanineCu(II)Pc-PAA was then dropcasted onto the activated silicon nitride surface. This was confirmed by the increase of CAM to $32^{\circ}$ after functionalization (Figure 3C). The hydrophilic character was retained, even with a small increase in the CAM. This confirms a successful deposition of the polymeric membrane onto silicon nitride surface. The hydrophilicity was due to the presence of hydroxyl groups in the phtalocyanine membrane, whereas the small increase in the CAM was attributed to the presence of aromatic rings that contained carbon atoms.

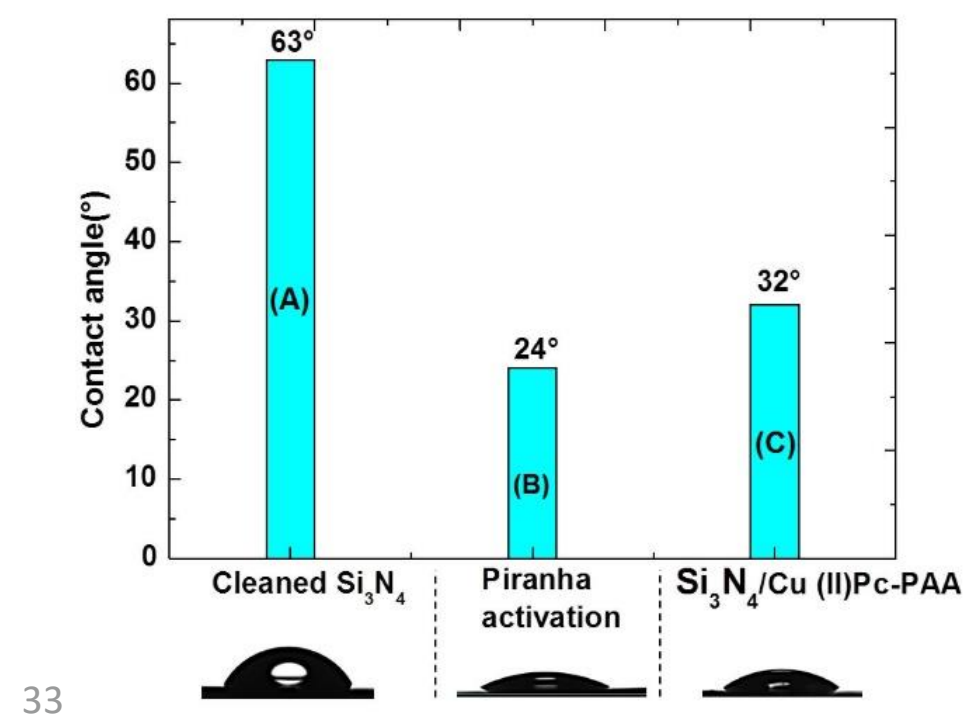

Fig. 3. Water contact angle measurements of bare $\mathrm{Si}_{3} \mathrm{~N}_{4}$ surface (A), after piranha treatment (B), and after surface modification with membrane copper phthalocyanine (C). Below: images of $5 \mu \mathrm{L}$ water droplet evolution onto silicon nitride surface at each step of its chemical surface modification.

\subsection{Atomic Force Microscopy Characterization}

The AFM images for the bare electrode and for the $\mathrm{Cu}$ (II)Pc-PAA deposited membrane in the surface of the silicon nitride $\mathrm{Si}_{3} \mathrm{~N}_{4}$ are shown in Figure $4 \mathrm{~A}$ and Figure B, respectively. The bare silicon nitride showed a homogenous surface with a RMS roughness of $0.088 \mathrm{~nm}$. This confirms the smooth aspect of silicon nitride surface. After being functionalized with phtalocyanine, the topography of the surface has totally changed and presents a homogenous morphological character of the polymeric membrane with a roughness of $7.53 \mathrm{~nm}$. The texture and the ripple of the polymeric surface were very pronounced and they gave a tridimensional aspect to the surface of $\mathrm{Cu}(\mathrm{II}) \mathrm{Pc}-\mathrm{PAA}$. This was very important for the sensitivity of the membrane as the higher the surface roughness, the greater the number of surface sites were available and thus the chemical sensor would become more sensitive. 


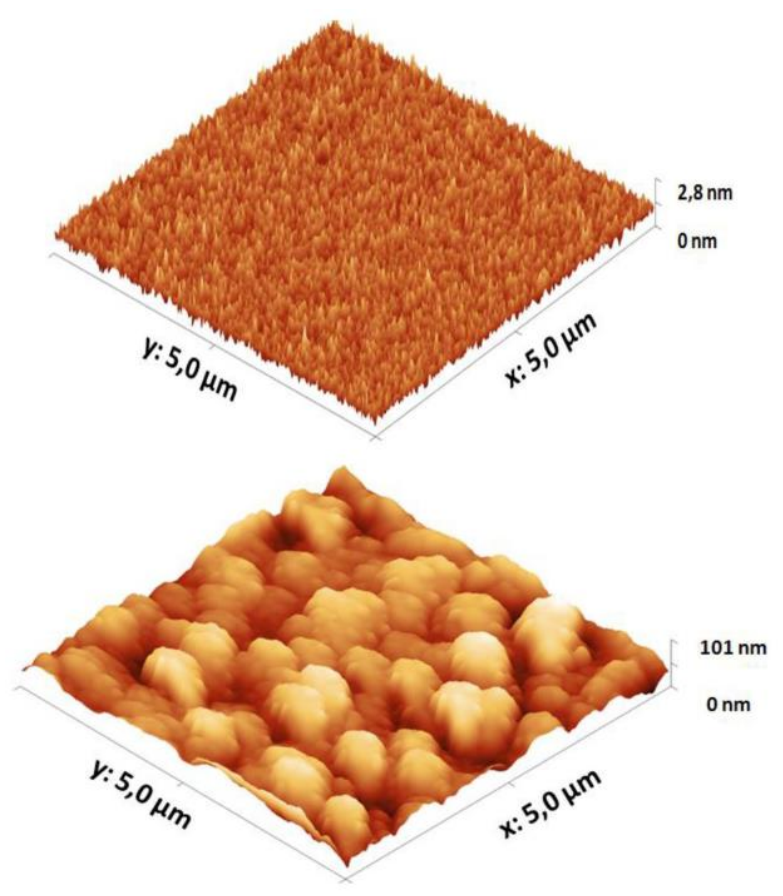

Fig. 4. AFM image, bare transducer $\mathrm{Si}_{3} \mathrm{~N}_{4}(\mathrm{~A})$ and transducer $\mathrm{Si}_{3} \mathrm{~N}_{4}$ after modification surface with membrane copper phthalocyanine (B).

\section{Results and Discussion}

\subsection{Effect of Frequency}

Typical $\mathrm{C}(\mathrm{V})$ curves with different frequencies ranging from $100 \mathrm{~Hz}$ to $10 \mathrm{kHz}$ of the capacitive chemical sensor recorded in a Tris- $\mathrm{HCl}$ buffer solution $0.1 \mathrm{M}$ at pH 7.2 are presented in Figure 5. At the quasi-static frequencies of $100 \mathrm{~Hz}$, the capacitance curves of this structure showed a well-known low-frequency behavior with typical accumulation, depletion and inversion regions [24]. The capacitance rose up to $\mathrm{C}_{\max }$ by decreasing the frequency in the inversion region. At a quasi-static frequency, the $C_{\max }$ in the inversion region was similar to $C_{\max }$ in the accumulation region. Similar effects were observed in the capacitance structures modified with selective membranes [25, 26]. 


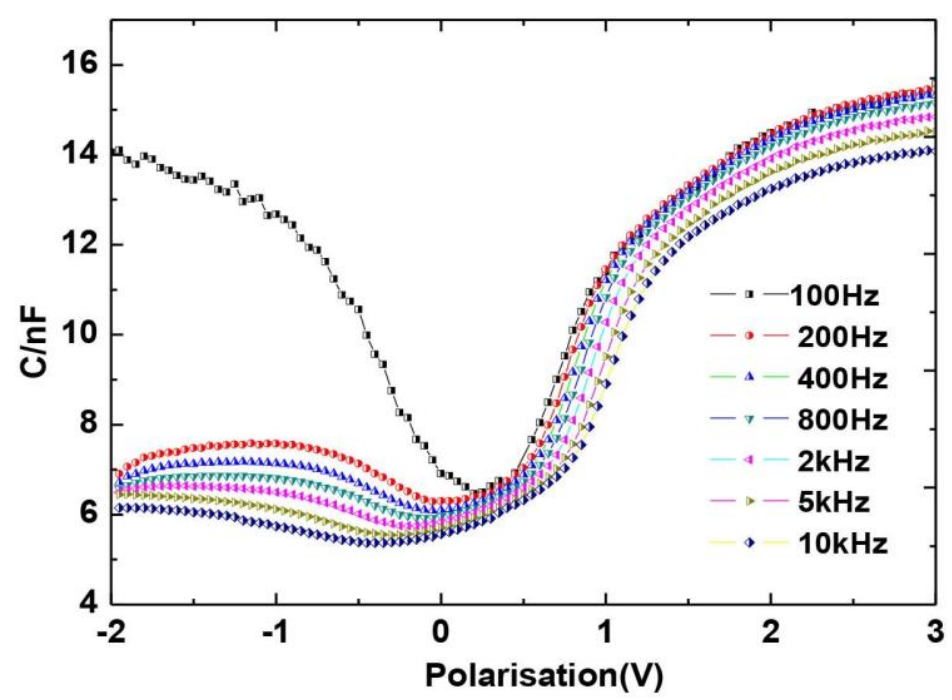

Fig. 5. Capacitance measurements (C) as a function of potential (V) for different frequency ranges for EIS structure.

Similarly, the capacitance measurements for the chemical sensor were performed in Tris- $\mathrm{HCl}$ buffer solution $0.1 \mathrm{M}$ at $\mathrm{pH} 7.2$ at high and quasi-static frequency from $-2 \mathrm{~V}$ to $3 \mathrm{~V}$. Figure 6, illustrates the vastly different characteristics of the $\mathrm{CV}$ curves measured at high and quasi-static frequency for a $\mathrm{p}$ type semiconductor. The capacitance depends on the voltage value applied to the device structure [27]. The three regions associated with this graph were accumulation, depletion, and inversion [28]. Therefore, at high frequency, the generation time of the pair electron-hole and the creation of an inversion layer could not follow the applied potential to the device.

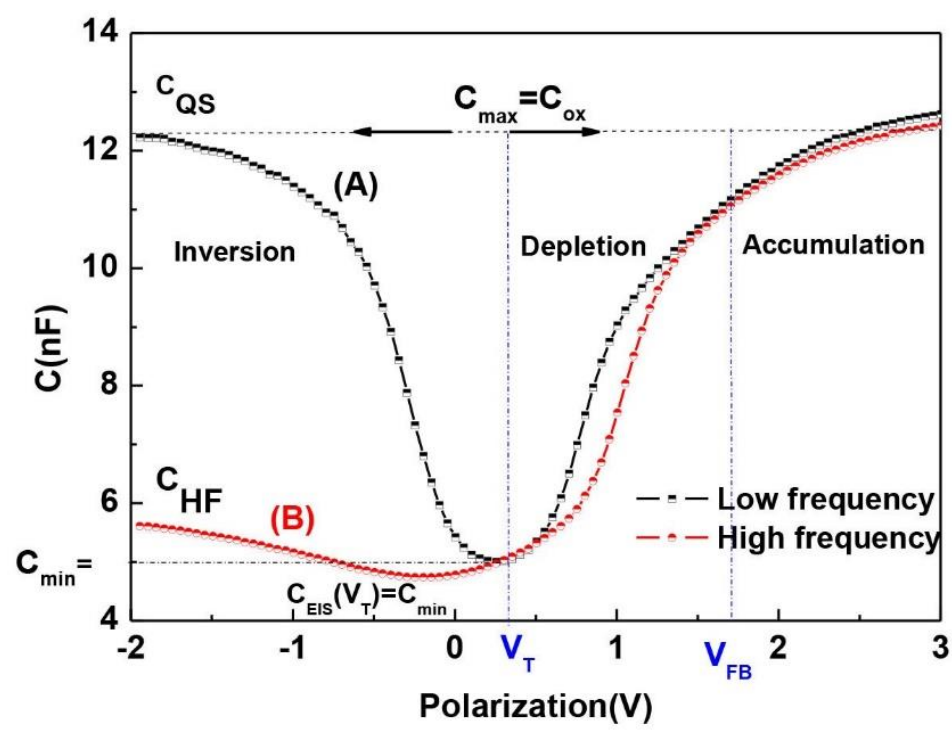

Fig. 6. C-V curves obtained by using Mott-Schottky analysis. The potential applied to the capacitance chemical sensor at (A) quasi-static measuring frequency and at (B) high frequency, $\mathrm{C}_{\max }$ : maximum capacitance of structure, $\mathrm{C}_{\mathrm{QS}}$ : quasi-static capacitance, $\mathrm{C}_{\mathrm{HF}}$ : highfrequency capacitance, $\mathrm{C}_{\mathrm{min}}$ : minimum capacitance of structure, $\mathrm{V}_{\mathrm{FB}}$ : flat band voltage, $\mathrm{V}_{\mathrm{T}}$ : threshold voltage. 
Thus, once the depletion reached its maximum width, the capacitance structure (C) measured at high frequency would be based only on the distribution of the majority carriers (hole). Under these conditions, the total capacity measured at high frequencies was the capacitance of the silicon oxide layer $\left(\mathrm{C}_{\mathrm{ox}}\right)$ in series with another capacitance associated to the maximum depletion zone [29]. Finally, the total capacity of the structure would reach a minimum and it would be independent from the applied voltage.

At low frequencies, in the inversion zone, when the electrons could follow the applied potential, the maximum capacitance would correspond to the capacity of the oxide and it would be a similar capacitance in the case of accumulation zone. Hence, the characteristic $\mathrm{C}(\mathrm{V})$ in the inversion region would depend on the frequency according to the minority carriers able to follow the applied potential.

In this case, two capacitances should be considered, one relating to the space charge regions and the other for the double layer. Since the capacitances were in series, the total capacitance was the sum of their reciprocals. As the space charge capacitance was much smaller than the double layer capacitance, the double layer capacitance contribution to the total capacitance was negligible. Consequently, the capacitance value calculated from this model was assumed to be the value of the space charge capacitance.

\section{2. $\mathrm{pH}$ Sensitivity of the $\mathrm{Al}-\mathrm{Cu} / \mathrm{Si}-\mathrm{p} / \mathrm{SiO}_{2} / \mathrm{Si}_{3} \mathrm{~N}_{4}$ Transducer}

In this study, the silicon nitride $\left(\mathrm{Si}_{3} \mathrm{~N}_{4}\right)$ substrate was used due to its high stability, low drift, low permeability and low structural porosity. Therefore, the capacitance structure $\mathrm{AlCu} / \mathrm{Si}$-p/ $/ \mathrm{SiO}_{2} / \mathrm{Si}_{3} \mathrm{~N}_{4}$ was tested first for $\mathrm{pH}$ measurements $[30,31]$ in order to validate its behavior toward $\mathrm{H}^{+}$ions. Then, the same transducer was used for phosphate detection using a sensitive membranes [32].

Silicon nitride surface was characterized only in Tris solution within the $\mathrm{pH}$ range $\mathrm{pH} 4$ to $\mathrm{pH} 10$. Figure $7 \mathrm{~A}$ represents a set of Mott-Schottky curves of bare silicon nitride at different $\mathrm{pH}$. Here, the horizontal shift of the flat band voltage $\left(\Delta \mathrm{V}_{\mathrm{FB}}\right)$ was increased toward positive values by decreasing the $\mathrm{pH}$. This change of the flat band voltage $\left(\Delta \mathrm{V}_{\mathrm{FB}}\right)$ could be explained by the presence of both $\mathrm{H}^{+}$ and $\mathrm{Si}-\mathrm{NH}_{2}$ groups at the sensors surface [24]. The $\mathrm{pH}$ sensitivity was calculated from the slope of the flat band voltage [33], which was obtained from Mott-Schotky curves (Figure 7B). Here, the average Nernstian sensitivity was $51 \mathrm{mV} / \mathrm{pH}$, which was in good agreement with the results obtained in the literature using $\mathrm{Si}_{3} \mathrm{~N}_{4} \mathrm{pH}$ sensors (Table 1). This $\mathrm{pH}$ test allowed checking the good capacitance structure and the working electrode interactivity.

Table 1. Performances of some $\mathrm{Si}_{3} \mathrm{~N}_{4} \mathrm{pH}$ sensors reported in the literature.

\begin{tabular}{lll}
\hline Tranducer & Sensitivity & Reference \\
\hline $\mathrm{SiO}_{2} / \mathrm{Si}_{3} \mathrm{~N}_{4}$ ISFET & $54 \mathrm{mV} / \mathrm{pH}$ & {$[23]$} \\
$\mathrm{Si}_{3} \mathrm{~N}_{4}$ ISFET & $46 \mathrm{mV} / \mathrm{pH}$ & {$[34]$} \\
$\mathrm{Si}_{3} \mathrm{~N}_{4}$ ISFET & $50.1 \mathrm{mV} / \mathrm{pH}$ & {$[35]$} \\
$\mathrm{Al} / \mathrm{p}-\mathrm{Si} / \mathrm{SiO}_{2} / \mathrm{Si}_{3} \mathrm{~N}_{4}$ & $51 \mathrm{mV} / \mathrm{pH}$ & This work \\
\hline
\end{tabular}




\section{3. $\mathrm{pH}$ Effect on the Phosphate Detection}

The phosphate phtalocyanine sensitive membrane was drop casted onto the activated silicon nitride surface, as previously described. Accordingly, the phosphate ions $\mathrm{HPO}_{4}{ }^{2-}$ were detected at $10^{-8} \mathrm{M}$ within the range of $\mathrm{pH} 5$ to $\mathrm{pH} 10$. The $\mathrm{pH}$ adjustments were tested in Tris-HCl buffer $(0.1 \mathrm{M})$. The same behavior of $\mathrm{pH}$ variation was observed for the Mott-Schottky analyses (Figure $8 \mathrm{~A}$ ). The variation of the flat band voltage $\left(\Delta \mathrm{V}_{\mathrm{FB}}\right)$ was plotted versus $\mathrm{pH}$ and showed almost stable potential between $\mathrm{pH} 7$ and $\mathrm{pH} 8$ (Figure $8 \mathrm{~B}$ ). The variation of the potential at $\mathrm{pH} \leq 7$ could be related to the protonation of the ionophore in the membrane which resulted in a loss of its ability to interact with $\mathrm{HPO}_{4}{ }^{2-}$ ions $[36,37]$. At higher $\mathrm{pH}(>8.0)$, the potential increasing may be attributed to the formation of hydroxyl-complexes of $\mathrm{Cu}^{2+}$ in solution. For the rest of the analyses, the phosphate detection was made in $\mathrm{pH} 7.2$ as it was in the range of $\mathrm{pH}$ where the potential was found stable. Moreover, this $\mathrm{pH}$ was close to the $\mathrm{pH}$ of the physiological mediums which give the possibility to perform ions detection complex environments.
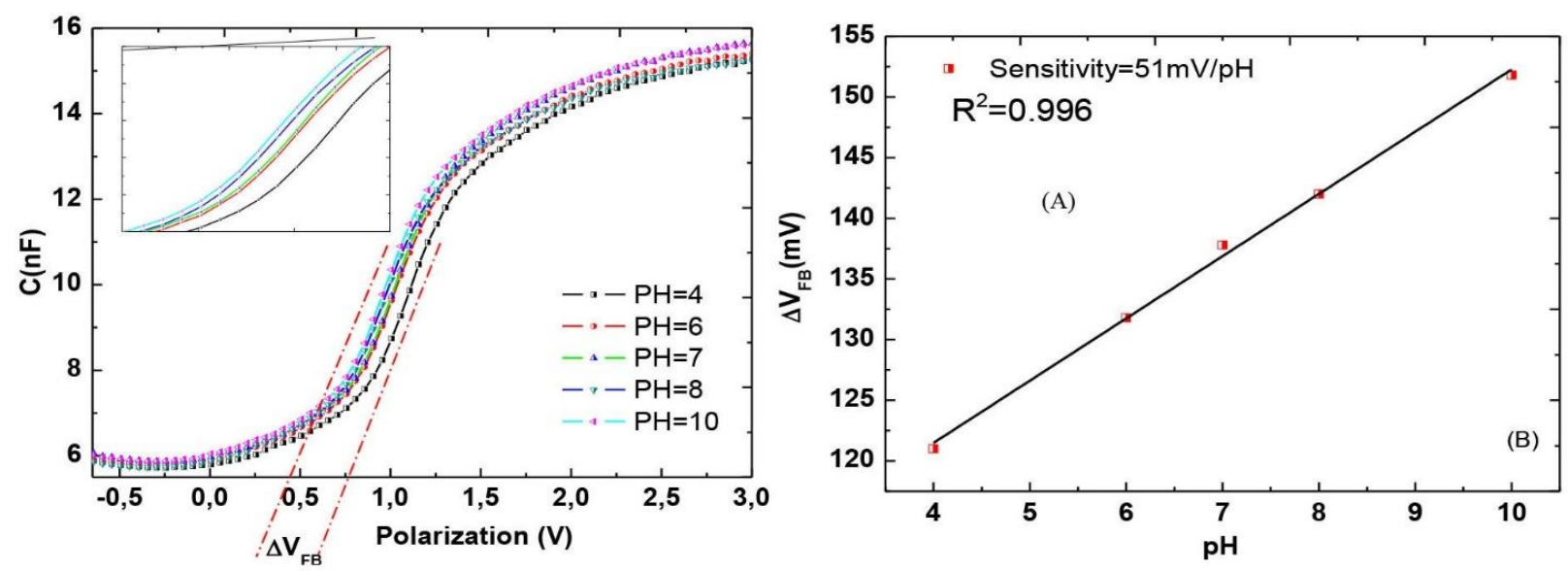

Fig. 7. (A), $\mathrm{pH}$ response of $\mathrm{AlCu} / \mathrm{Si}-\mathrm{p} / \mathrm{SiO}_{2} / \mathrm{Si}_{3} \mathrm{~N}_{4}$ chemical sensor (B), Sensitivity of chemical sensor versus different $\mathrm{pH}$ values.
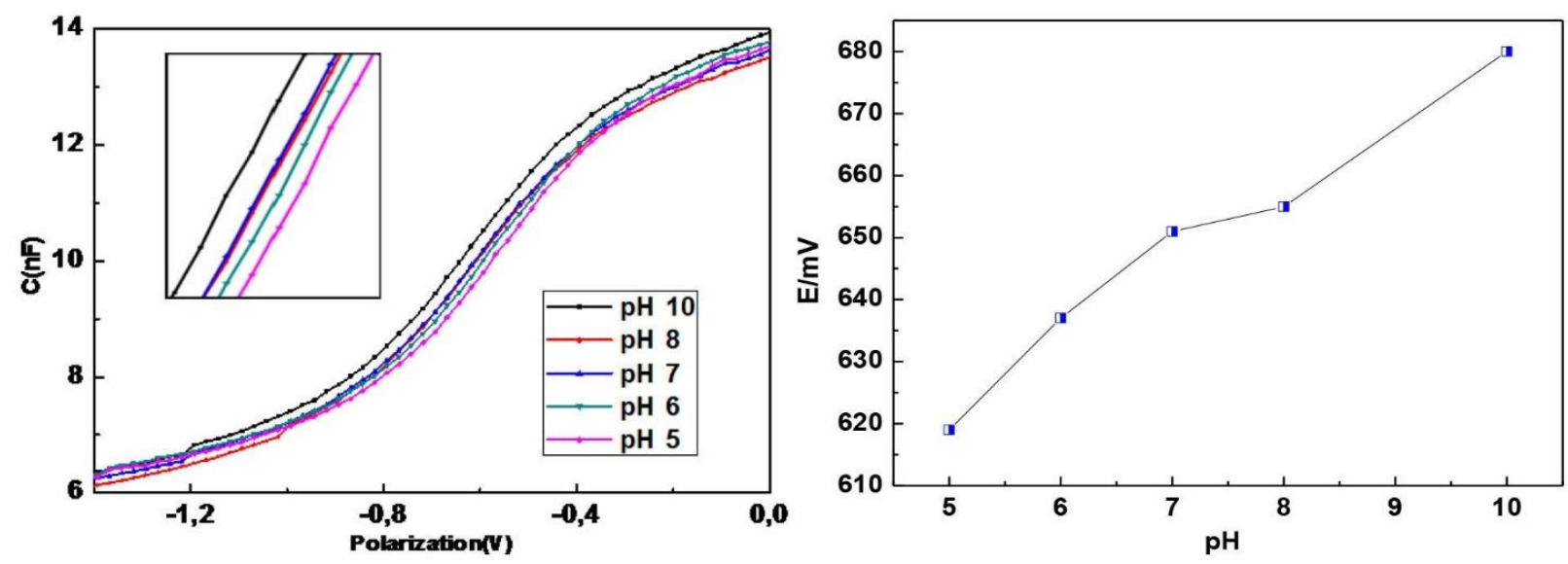

Fig. 8. pH effect on the flat band potential response of the $\mathrm{Cu}(\mathrm{II}) \mathrm{Pc}-\mathrm{PAA}$ modified $\mathrm{AlCu} / \mathrm{Si}$ $\mathrm{p} / \mathrm{SiO}_{2} / \mathrm{Si}_{3} \mathrm{~N}_{4}$ chemical sensor for phosphate detection. 


\subsection{Mott-Schottky Analysis for Bare and Functionalized Chemical Sensors}

The adsorption of the $\mathrm{Cu}(\mathrm{II}) \mathrm{Pc}-\mathrm{PAA}$ layer was characterized by the capacitance voltage method at a fixed frequency of $10 \mathrm{kHz}$. The measurements were performed in Tris- $\mathrm{HCl}$ buffer solution ( $\mathrm{pH} 7.2)$ in a Faraday cage at room temperature.

Figure 9 shows the $\mathrm{CV}$ measurements of the sensor before and after functionalization with $\mathrm{Cu}(\mathrm{II}) \mathrm{Pc}-$ PAA membrane. Indeed, the total capacitance $\mathrm{C}$ in the accumulation region has dramatically decreased after the deposition of the sensitive membrane $\mathrm{Cu}(\mathrm{II}) \mathrm{Pc}$-PAA onto the transducer. This was due to an increase in the insulator thickness after dropping this material. The capacity was inversely proportional to the thickness according to the following equation [14]:

where $C$ is the capacitance of the structure, $\varepsilon=\varepsilon_{0} \varepsilon_{\mathrm{r}}$ or $\varepsilon_{0}$ is the dielectric permittivity of the vacuum, $\varepsilon_{\mathrm{r}}$ is the dielectric permittivity of the insulator, $\mathrm{S}$ is the surface of the working electrode, and $\varepsilon$ is the insulator thickness.

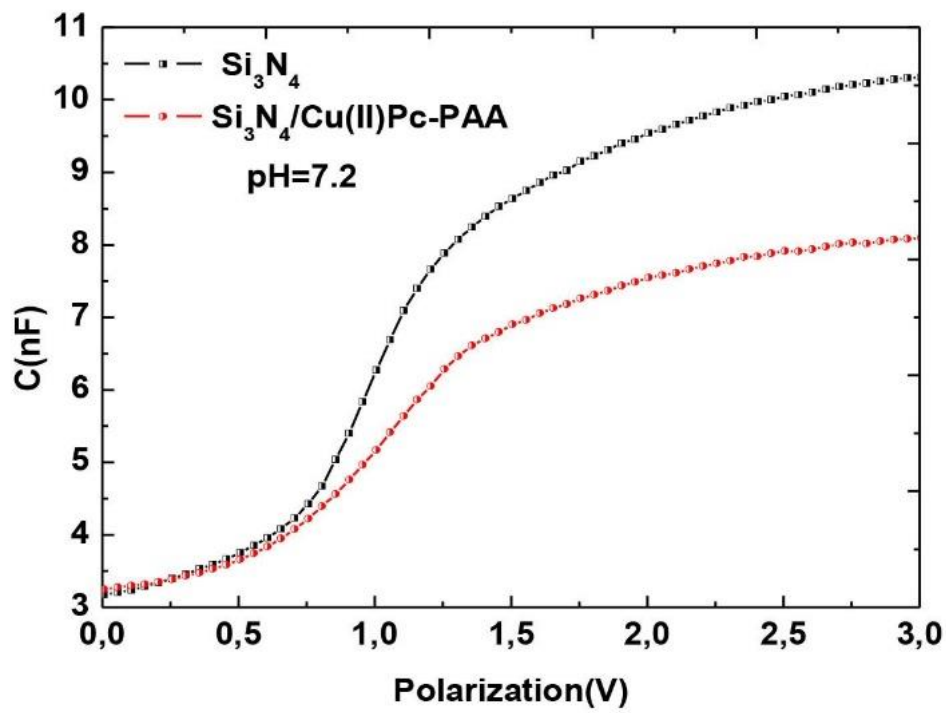

Fig. 9. Mott-Schottky analyses for bare $\mathrm{AlCu} / \mathrm{Si}-\mathrm{p} / \mathrm{SiO}_{2} / \mathrm{Si}_{3} \mathrm{~N}_{4}$ and $\mathrm{Cu}$ (II) Pc-PAA modified capacitance chemical sensor in Tris buffer solution of $\mathrm{pH}$ 7.2.

\subsection{Functionalized EIS Structure Response Towards $\mathrm{HPO}_{4}{ }^{2-}$ Ions}

After optimizing all different parameters in different conditions, the capacitive chemical sensor was tested for the detection of phosphate ions by capacitance measurements. Therefore, the $\mathrm{AlCu} / \mathrm{Si}$ $\mathrm{p} / \mathrm{SiO}_{2} / \mathrm{Si}_{3} \mathrm{~N}_{4} / \mathrm{Cu}(\mathrm{II}) \mathrm{Pc}-\mathrm{PAA}$ structure was tested for different $\mathrm{HPO}_{4}{ }^{2-}$ concentrations and at a fixed frequency of $10 \mathrm{kHz}$, as presented in Fig.10. Subsequently, a significant variation of the potential of the flat band voltage $\mathrm{V}_{\mathrm{FB}}$ in the depletion range was observed by increasing $\mathrm{HPO}_{4}{ }^{2-}$ concentration. This could be explained by the change of the potential at the surface after the axial ligation of $\mathrm{HPO}_{4}{ }^{2-}$ to the metallic center (which is copper $(\mathrm{Cu})$ in this study) of the phthalocyanine derivative [38]. In 
addition, a slight change of capacitance in the regime of accumulation was noticed and was accompanied with a $\mathrm{V}_{\mathrm{FB}}$ variation. This change was clearly related to the dielectric constant and the thickness changes due to the adsorption of charged species at the $\mathrm{Cu}$ (II)-Pc-PAA membrane surface.

To determine the $\mathrm{HPO}^{2}{ }_{4}$ sensor sensitivity, the $\mathrm{V}_{\mathrm{FB}}$ variation $\left(\Delta \mathrm{V}_{\mathrm{FB}}\right)$ was plotted as a function of $\mathrm{HPO}_{4}{ }^{2-}$ concentration (Fig. 10B). A comparison with data available from literature for other types of phosphate sensors is presented in Table 2. Here, the $\mathrm{Al} / \mathrm{Si} \mathrm{p} / \mathrm{SiO}_{2} / \mathrm{Si}_{3} \mathrm{~N}_{4} / \mathrm{Cu}$ (II)Pc-PAA based chemical sensor presented in this work has shown a sensitivity of $27.7 \mathrm{mV} /$ decade at high frequency $10 \mathrm{kHz}$ and $32 \mathrm{mV} /$ decade at quasi-static frequency $100 \mathrm{~Hz}$ for phosphate ions detection. This chemical sensor was tested in a large phosphate concentration range and proving a low detection limit of $1 \mathrm{nM}$.

The sensitivity from the slope of the linear part was calculated at $27.7 \mathrm{mV} / \mathrm{decade}$, which was in good agreement with the Nernstian behavior for divalent ions. The obtained results allowed to confirm the interesting performances for the $\mathrm{HPO}_{4}{ }^{2-}$ detection using the new receptor material (Cu(II)-Pc-PAA). Compared to other developed phosphate sensor [10], the detection limit was $1 \mathrm{nM}$ within the detection range of $10^{-10} \mathrm{M}$ to $10^{-6} \mathrm{M}$.

The increase of the capacitance depends on the ability of the electron concentration to follow the applied AC signal. This happens only at low frequencies where the recombination-generation rates of minority carriers (in our example, electrons) can keep up with the small-signal variation and lead to charge exchange with the inversion layer during the signal measurements. Unlike depletion and weak inversion, at strong inversion the incremental charge is no longer at the edge of the depletion region but at the semiconductor surface inversion layer, resulting in a large capacitance [26]. Experimentally, the range in which the capacitance is most frequency dependent was found between $100 \mathrm{~Hz}$ and $10 \mathrm{kHz}$ for the capacitance structures. This is related to the carrier lifetime in the silicon substrate. As a consequence, capacitive curves measured at higher frequencies do not show the increase of capacitance in strong inversion [27].

Table 2. Performances of some phosphate ion sensors reported in the literature.

\begin{tabular}{|c|c|c|c|c|}
\hline Interface & Electrochemical technique & $\begin{array}{l}\text { Detection limit } \\
(\mathrm{mM})\end{array}$ & $\begin{array}{l}\text { Linear range } \\
(\mathrm{mM})\end{array}$ & References \\
\hline $\mathrm{PyO} /$ nano-CPGCE & Stirred batch amperometry & 0.3 & 1 to 100 & [39] \\
\hline Co m-electrode & Potentiometry & $<10$ & 10 to 10000 & [40] \\
\hline PB-GCE & Differential pulse voltammetry & 38.3 & 500 to 5000 & [41] \\
\hline GLA-PyO-CoPC-SPE & Stirred batch amperometry & 2.28 & 2.5 to 50 & [42] \\
\hline Gold rotating electrode & Stirred batch amperometry & 0.11 & 0.59 to 3.49 & [43] \\
\hline CB-SPE & Stirred batch amperometry & 0.1 & 0.5 to 100 & [44] \\
\hline CB-SPE & Continuous flow amperometry & 6 & 10 to 80 & [45] \\
\hline $\begin{array}{l}\mathrm{Al}-\mathrm{Cu} / \mathrm{Si}-\mathrm{p} / \mathrm{SiO}_{2} / \mathrm{Si}_{3} \mathrm{~N}_{4} / \mathrm{Cu}(\mathrm{II}) \mathrm{Pc}- \\
\mathrm{PAA} \text { at } 10 \mathrm{kHz} \text { frequency }\end{array}$ & Capacitance-voltage & 0.001 & 0.0001 to 1 & This work \\
\hline $\begin{array}{l}\mathrm{Al}-\mathrm{Cu} / \mathrm{Si}-\mathrm{p} / \mathrm{SiO}_{2} / \mathrm{Si}_{3} \mathrm{~N}_{4} / \mathrm{Cu}(\mathrm{II}) \mathrm{Pc}- \\
\mathrm{PAA} \text { at } 100 \mathrm{~Hz} \text { frequency }\end{array}$ & Capacitance-voltage & 0.001 & 0.0001 to 10 & This work \\
\hline
\end{tabular}

PyO : Pyruvate Oxidase; SPE: Screen Printed Electrode; CoPc/SPCE: Cobalt (II) phthalocyanine/Screen printed carbon electrode. 

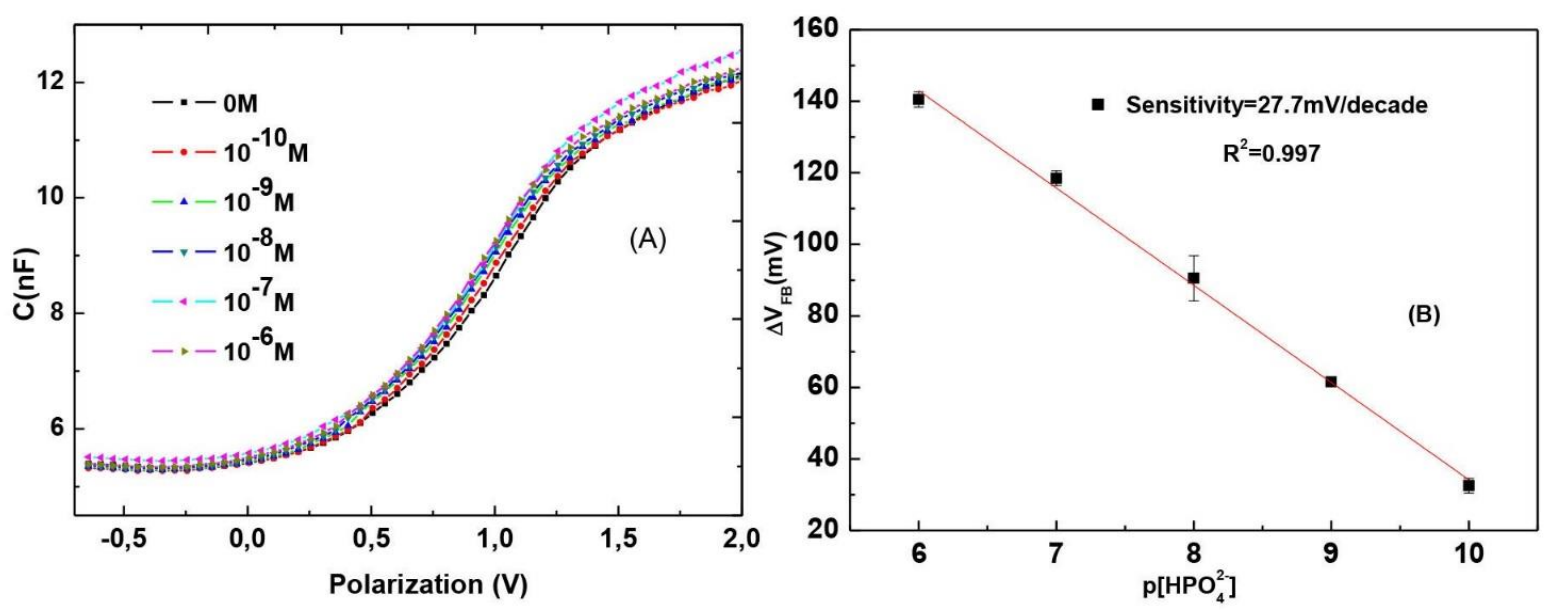

Fig. 10. (A) Variation of capacitance various potential for $\mathrm{AlCu} / \mathrm{Si}$-p/SiO$/ \mathrm{Si}_{2} / \mathrm{Si}_{3} \mathrm{~N}_{4}$ structure functionalized with a $\mathrm{Cu}$ (II) Pc-PAA for 19 different phosphate ion concentrations. Buffer solution, Tris-HCl $10 \mathrm{mM}, \mathrm{pH} 7.2, \mathrm{f}=10 \mathrm{kHz}$. (B) Sensor sensitivity.
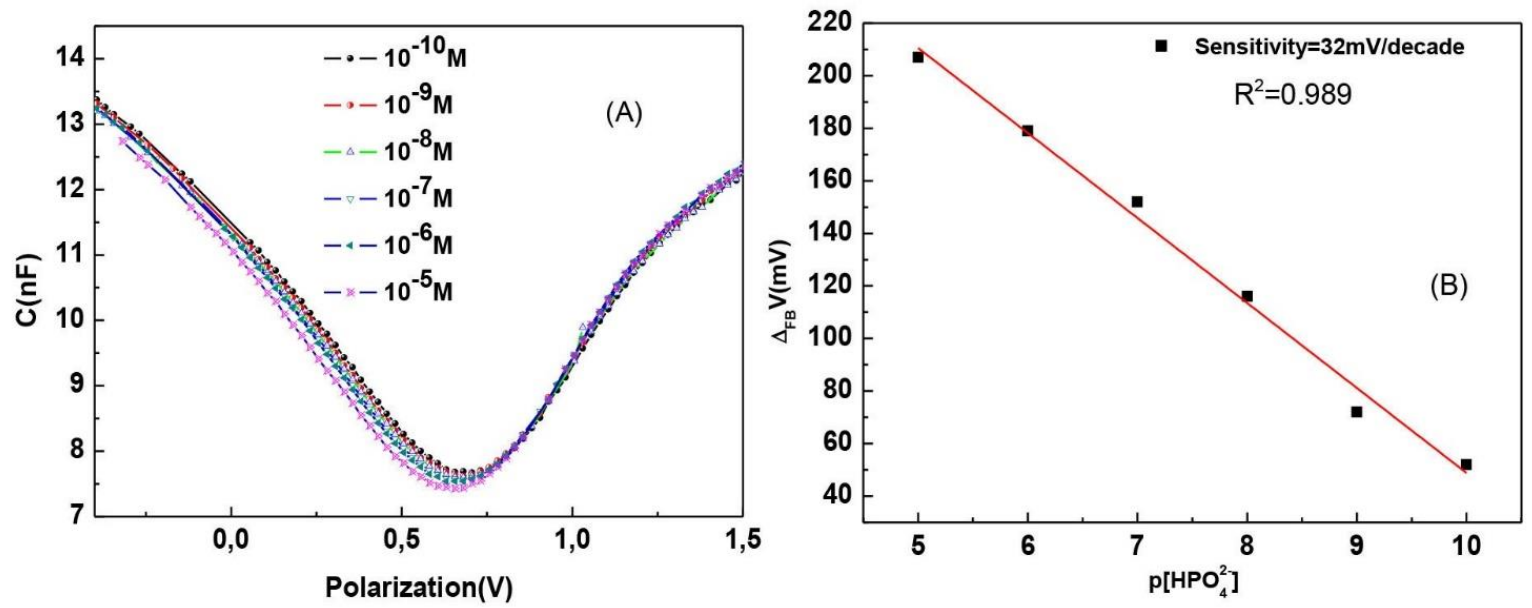

Fig. 11. (A) The variation of flat band potential of $\mathrm{AlCu} / \mathrm{Si}-\mathrm{p} / \mathrm{SiO}_{2} / \mathrm{Si}_{3} \mathrm{~N}_{4} / \mathrm{Cu}$ (II)Pc-PAA structure plotted versus phosphate ion concentrations, buffer solution, Tris- $\mathrm{HCl} 10 \mathrm{mM}, \mathrm{pH}$ $7.2, \mathrm{f}=100 \mathrm{~Hz}$ (B) Sensitivity of the sensor as function of phosphate ion concentrations.

The same study of phosphate detection was performed within the same range potential at low frequency of $100 \mathrm{~Hz}$ (Figure 11). In the inversion regime, the capacitance at extremely low frequencies of the order of some $\mathrm{Hz}$, suffers from too much noise or parasitic capacitances. If there are many electrons at the oxide semi-conductor interface (in inversion regime for capacitance structure with a p-type substrate), there would be transition probability of the semiconductor electrons to the traps in the oxide. This probability would depend on the distance between the loads and the semiconductor-insulator interface area, as well as the barrier height between the two states.

Figure $11 \mathrm{~A}$ shows the $\mathrm{C}(\mathrm{V})$ curves with $\Delta \mathrm{V}_{\mathrm{FB}}$ as a parametric variable. This shifted along the voltage axis without any change in their shape. The flat-band voltage shift was plotted as a function of the concentration of phosphate ions. Figure 11B, illustrates the chemical sensor response near the Nernstian response, equal to $32 \mathrm{mV} /$ decade. 


\subsection{Interference Study}

The specificity is one of the most important characteristics of a chemical sensor. The capacitance chemical sensor $\mathrm{AlCu} / \mathrm{Si}-\mathrm{p} / \mathrm{SiO}_{2} / \mathrm{Si}_{3} \mathrm{~N}_{4} / \mathrm{Cu}$ (II)Pc-PAA has demonstrated a higher preference for $\mathrm{HPO}_{4}{ }^{2-}$ ions when compared to other examined ions such as chloride $\mathrm{Cl}^{-}$, sulfate $\mathrm{SO}_{4}{ }^{2-}$, carbonate $\mathrm{CO}_{3}{ }^{2-}$ and perchlorate $\mathrm{ClO}_{4}{ }^{2-}[36]$. The flatband voltage shift $\Delta \mathrm{V}_{\mathrm{FB}}$ of these interferences was plotted and compared to the responses of $\mathrm{HPO}_{4}{ }^{2-}$ (Figure 12). The linear parts of the potential responses of the chemical sensors for all other ions were much lower when compared to the main ion $\mathrm{HPO}_{4}{ }^{2-}$.

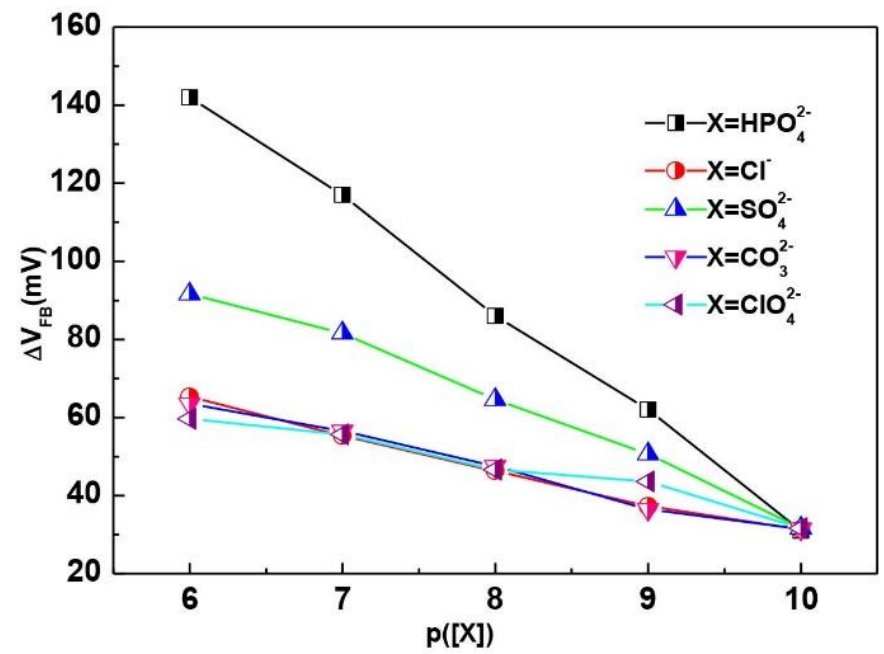

Fig. 12. Evolution of depletion capacitance as a function of $\mathrm{Cl}^{-}, \mathrm{SO}_{4}{ }^{2-}, \mathrm{CO}_{3}{ }^{2-}$ and $\mathrm{CIO}_{4}{ }^{2-}$ ions. Test solution Tris $10 \mathrm{mM}$ and $\mathrm{pH}$ 7.2.

The sensitivity of ions adsorbed onto receptor layer copperphthalocyanine $\mathrm{Cu}(\mathrm{II}) \mathrm{Pc}-\mathrm{PAA}$ is presented in Table 3. Here the new material $\mathrm{Cu}$ (II)Pc-PAA was highly sensitive for phosphate ions when compared to the other interferences. As all other interfering ions were also detected at $10^{-10} \mathrm{M}$, the chemical sensor could be classified as selective for phosphate ions from $10^{-9} \mathrm{M}$.

Table 3. Specificity of phosphate adsorption onto copper phthalocyanine $\mathrm{Cu}$ (II)Pc-PAA capacitance chemical sensor.

\begin{tabular}{ll}
\hline Target ion & Sensitivity (mV/decade) \\
\hline $\mathrm{Cl}^{-}$ & 8.6 \\
$\mathrm{SO}_{4}{ }^{2-}$ & 15 \\
$\mathrm{CO}_{3}{ }^{2-}$ & 8.4 \\
$\mathrm{ClO}_{4}{ }^{2-}$ & 6.8 \\
$\mathrm{HPO}_{4}{ }^{2-}$ at $\mathrm{F}=10 \mathrm{kHz}$ & 27.7 \\
$\mathrm{z}$ & 32 \\
\hline
\end{tabular}




\section{Conclusion}

The capacitive electrochemical ion sensor has been developed in the present study using a new derivative copper phthalocyanine $\mathrm{Cu}(\mathrm{II})-\mathrm{Pc}-\mathrm{PAA}$ as sensitive layer for phosphate ion detection. The capacitance structure of the chemical sensor has been based on $\mathrm{AlCu} / \mathrm{Si}-\mathrm{p} / \mathrm{SiO}_{2} / \mathrm{Si}_{3} \mathrm{~N}_{4}$, which is a stable configuration and stable combination of materials for electrochemical measurements. The behavior of the capacitance structure has been studied at low and high frequencies for the detection of phosphate ions. These ions have been detected by the variation of the capacitance as function of the applied potential $(\mathrm{C}(\mathrm{V}))$ using the Mott-Schottky technique. The phosphate ions were detected selectively within the range $\left(10^{-10}\right.$ to $\left.10^{-5} \mathrm{M}\right)$ and the limit of detection has been found to be $1 \mathrm{nM}$. These improved performances have been explained by the physical properties of the capacitance structure of the WE, the Nernstian sensitivity, and repeatability of measurements. The specificity of the $\mathrm{AlCu} / \mathrm{Si}-\mathrm{p} / \mathrm{SiO}_{2} / \mathrm{Si}_{3} \mathrm{~N}_{4} / \mathrm{Cu}$ (II)Pc-PAA chemical sensor has been also investigated in relation to other interfering ions: $\mathrm{Cl}^{-}, \mathrm{SO}_{4}{ }^{2-}, \mathrm{CO}_{3}{ }^{2-}$ and $\mathrm{CIO}_{4}{ }^{2-}$. This could be very promising and was suitable for the study of the removal of phosphate in rivers, lakes, and seas.

\section{Acknowledgements}

This work was partially supported by the European Commission $7^{\text {th }}$ Framework Programme Marie Curie Actions IRSES FP7-PEOPLE-2012-IRSES N8 318053: SMARTCANCERSENS project and the NATO Science for Peace (SFP) Project CBP.NUKR.SFP 984173. We acknowledge the funding through the European Communities Seventh Framework Programme project named Sea-on-a-Chip (FP7-OCEAN-2013) (No.614168) and the funding from the European Union's Horizon 2020 research and innovation programme project named HEARTEN under grant agreement No 643694, and the European project H2020-FCT-2014 named micro-Mole under the grant 653626.

\section{References}

[1] B. Geissler, M. C. Mew, O. Weber, G. Steiner, Resour Conserv Recy Part B 2015, 105, 246-258.

[2] R. al Rawashdeh, P. Maxwell, Mineral Econ 2011, 24, 15, 27.

[3] N. Mokadem, Y. Hamed, A. B. Sâad, I. Gargouri, AJG 2014, 7, 2071-2079.

[4] F. Ogata, A. Ueda, S. Tanei, D. Imai, N. Kawasaki, Ind. Eng. Chem 2016, 35, 287-294.

[5] F. Kivlehan, W. J. Mace, H. A. Moynihan, D. W. M. Arrigan, Anal. Chim. Acta 2007, 585, 154160.

[6] J. Nie, J.-P. Li, H. Deng, H.-C. Pan, Chin. J. Anal. Chem 2015, 43, 609-617.

[7] J. Payandeh, D. L. Minor Jr, J. Mol. Biol 2015, 427, 3-30.

[8] W. Bala, M. Wojdyla, M. Rebarz, M. Szybowicz, M. Drozdowski, A. Grodzicki, P. Piszczek, JOAM 2009, 11, 264- 269.

[9] S. Shahrokhian, M. Ghalkhani, M. K. Amini, Sens. Actuators, B 2009, 137, 669-675.

[10] S. Shahrokhian, Anal. Chem 2001, 73, 5972-5978.

[11] J. Rossignol, G. Barochi, B. de Fonseca, J. Brunet, M. Bouvet, A. Pauly, L. Markey, Sens. Actuators, B 2013, 189, 213-216.

[12] Y.-Q. Zhang, Y.-J. Fan, L. Cheng, L.-L. Fan, Z.-Y. Wang, J.-P. Zhong, L.-N. Wu, X.-C. Shen, Z.-J. Shi, Electrochim. Acta 2013, 104, 178-184. 
[13] K. I. Ozoemena, T. Nyokong, Electrochim. Acta 2006, 51, 5131-5136.

[14] M. Braik, C. Dridi, A. Ali, M. N. Abbas, M. Ben Ali, A. Errachid, Org Electron 2015, 16, 7786.

[15] K. I. Ozoemena, T. Nyokong, Talanta 2005, 67, 162-168.

[16] L. Chen, T. Wang, Y. Zhao, X.-R. Zhang, Energy Convers. Manage 2014, 79, 317-333.

[17] H. Dang, X. Wu, X. Sun, R. Zou, R. Zhang, S. Yin, JoS 2015, 36, 104003.

[18] F. I. Bohrer, C. N. Colesniuc, J. Park, M. E. Ruidiaz, I. K. Schuller, A. C. Kummel, W. C. Trogler, J. Amer. Chem. Soc 2009, 131, 478-485.

[19] J.-Z. Li, X.-C. Wu, R. Yuan, H.-G. Lin, R.-Q. Yu, Analyst 1994, 119, 1363, 1366.

[20] M. N. Abbas, A. L. A. Radwan, N. M. Nooredeen, M. A. A. El-Ghaffar, J. Solid State Electrochem 2016, 20, 1599-1612.

[21] H. A. Moynihan, G. Claudon, Cryst.Eng.Comm 2010, 12, 2695-2696.

[22] M. A. A. El-Ghaffar, N. R. El-Halawany, H. A. Essawy, J. Appl. Polym. Sci 2008, 108, 32253232.

[23] B. Hajji, P. Temple-Boyer, J. Launay, T. do Conto, Microelectron Reliab 2000, 40, 783-786. [24] M. Bougrini, A. Baraket, T. Jamshaid, A. E. Aissari, J. Bausells, M. Zabala, N. E. Bari, B. Bouchikhi, N. Jaffrezic-Renault, E. Abdelhamid, N. Zine, Sens. Actuators, B 2016, 234, 446-452. [25] M. H. Abouzar, W. Moritz, M. J. Schöning, Phys. Status Solidi A 2011, 208, 1327-1332.

[26] B. Rong, L. K. Nanver, J. N. Burghartz, A. B. M. Jansman, A. G. R. Evans, B. S. Rejaei, ESSDERC 2003, 489-492.

[27] W. M. Siu, R. S. C. Cobbold, IEEE Trans. Electron Devices 1979, 26, 1805-1815.

[28] P. Fabry, L. Laurent-Yvonnou, Anal. Chim 1990, 286, 23-40.

[29] A. Demoz, E. M. J. Verpoorte, D. J. Harrison, J. Electroanal. Chem 1995, 389, 71-78.

[30] P. Bergveld, IEEE Trans Biomed Eng 1972, 19, 342-351.

[31] F. V. Gasparyan, A. Poghossian, S. A. Vitusevich, M. V. Petrychuk, V. A. Sydoruk, J. R. Siqueira, O. N. Oliveira, A. Offenhausser, M. J. Schoning, IEEE Sensors J 2011, 11, 142-149.

[32] S. Azzouzi, M. Ben Ali, M. N. Abbas, J.Bausells, N. Zine, A. Errachid, Org Electron 2016, 34, 200-207.

[33] L. Bousse, N. F. D. Rooij, P. Bergveld, IEEE Trans. Electron Devices 1983, 30, 1263, 1270.

[34] B. D. Liu, Y. K. Su, S. C. Chen, IJE 1989, 67, 59-63.

[35] S. Martinoia, G. Massobrio, L. Lorenzelli, Sens. Actuators, B 2005, 105, 14-27.

[36] M. R. Ganjali, P. Norouzi, N. Hatambeygi, M. SalavatiNiasari, J. Braz. Chem. Soc 2006, 17, 859-865.

[37] P. Kumar, D. M. Kim, M. H. Hyun, Y.-B. Shim, Talanta 2010, 82, 1107-1112.

[38] C. M. Drain, J. T. Hupp, K. S. Suslick, M. R. Wasielewski, X. Chen, J. Porphyr. Phthalocyanines JPP 2002, 06, 243-258.

[39] M. A. Rahman, D.-S. Park, S.-C. Chang, C. J. McNeil, Y.-B. Shim, Biosens. Bioelectron 2006, 21, 1116-1124.

[40] Z. Zou, J. Han, A. Jang, P. L. Bishop, C. H. Ahn, Biosens. Bioelectron 2007, 22, 1902-1907.

[41] L. Torrezani, A. A. Saczk, M. Firmino de Oliveira, N. R. Stradiotto, L. L. Okumura, Electroanalysis 2011, 23, 2456- 2461.

[42] L. Gilbert, A. T. A. Jenkins, S. Browning, J. P. Hart, Sens. Actuators, B 2011, 160, 1322-1327. [43] J. Jonca, W. Giraud, C. Barus, M. Comtat, N. Striebig, D. Thouron, V. Garçon, Electrochim. Acta 2013, 88, 165-169. 
[44] D. Talarico, F. Arduini, A. Amine, D. Moscone, G. Palleschi, Talanta 2015, 141, 267-272.

[45] D. Talarico, S. Cinti, F. Arduini, A. Amine, D. Moscone, G. Palleschi, Environ. Sci. Technol 2015, 49, 7934-7939.

Received: January 4, 2017

Accepted: March 7, 2017

Published online on March 23, 2017 